\title{
STRATEGI PENDIDIKAN ISLAM DALAM MENGHADAPI GLOBALISASI ILMU PENGETAHUAN DAN TEKNOLOGI
}

\section{Muchamad Agus Munir*}

\begin{abstract}
Abstrak: Secara umum pendidikan Islam di Indonesia sedang dihadapkan pada problem globalisasi ilmu pengetahuan dan tekhnologi. Terdapat berbagai macam tanggapan mulai dari yang negatif dan juga positif. Pendidikan Islam dapat mengalami dinamisasi apabila mampu menciptakan strategi dalam perkembangannya. Tulisan ini bertujuan untuk mengurai strategistrategi yang digunakan dalam pendidikan Islam agar dapat menghadapi globalisasi ilmu pengetahuan dan tekhnologi. Hasil temuan penelitian ini menunjukkan bahwa terdapat cara pandang yang lebih maju di dalam pendidikan Islam. Pendidikan Islam dalam sejarahnya dapat menciptakan kemajuan berkat adanya etos kerja yang ada di dalam individu-individunya, serta dapat berkembang maju melampaui zamannya dengan semangat tersebut.
\end{abstract}

Kata Kunci: Strategi Pendidikan Islam, Globalisasi Ilmu Pengetahuan, Teknologi.

\section{Pendahuluan}

$\mathrm{P}$

endidikan di era global saat ini sedang menghadapi tantangan besar, terutama jika dikaitkan dengan konstribusinya terhadap terbentuknya peradaban dan budaya modern yang relevan dengan perkembangan ilmu pengetahuan dan teknologi (Iptek). Pada dimensi ini, pendidikan

* Penulis adalah alumni Program Pascasarjana UIN Sunan Kalijaga Yogyakarta. Serta sebagai aktivis pendidikan yang tergabung di dalam Komunitas Rumah Kreasi Jihad Yogyakarta, dan aktif diberbagai forum Nasional yang konsen di dalam pendidikan Islam. Email: siapamirat@gmail.com 
(pendidikan Islam khususnya) mengalami kemunduran fungsi (degradasi fungsional), karena pendidikan Islam lebih berorientasi pada aspek batiniah daripada aspek lahiriah. Dengan demikian, pendidikan Islam menyebabkan terjadinya kemandulan dalam berpikir. Banyak pendapat yang mengatakan bahwa pendidikan Islam hanya mampu menyesuaikan diri dengan pendidikan yang berorientasi pada materialistik (praktis dan pragmatis) sehingga tidak mampu menentukan langkahnya dengan independen (Rahman 1987, 89). Hal ini terjadi sebagai akibat pendidikan Islam kalah bersaing dalam kebudayaan di tingkat global.

Dengan demikian, secara makro kondisi pendidikan Islam saat ini sudah ketinggalan jaman (out of date) karena kalah berpacu dengan perkembangan dan perubahan sosial budaya. Konservatisme pendidikan merupakan salah satu sebab yang dirasakan menjadi "hambatan" sehingga komoditi yang diproduksi pendidikan Islam selalu kalah bersaing dengan perkembangan ilmu pengetahuan dan teknologi. Kemajuan ilmu pengetahuan dan teknologi, misalnya, yang mendorong pertumbuhan industri komunikasi dan informasi yang sedikit banyak telah mengubah pergeseran nilai dan budaya yang ada dalam masyarakat. Lebih "celaka" lagi, pendidikan sebagai salah satu sistem sosial telah terbelenggu oleh berbagai aturan dan kebijakan pemegang kekuasaan yang menyebabkan pendidikan menjadi "mandul", tidak efektif, dan tidak fleksibel dalam menghadapi perkembangan ilmu pengetahuan dan teknologi di tengah kehidupan masyarakat.

Pendidikan formal (sekolah) tidak lagi adaptif, bahkan berada dalam status-quo (Ahmad 1991, 128), di mana output pendidikan formal tidak mampu memenuhi tuntutan masyarakat, yang pada akhirnya pendidikan hanya mampu menghasilkan "pengangguran terdidik" karena tidak tersedianya lapangan kerja yang sesuai. Hal tersebut merupakan realitas sosial (social reality) yang kita hadapi saat ini. Untuk memecahkan berbagai permasalahan di atas, dalam makalah ini penulis menawarkan solusi untuk ikut mengurai benang kusut yang menimpa dunia pendidikan kita. Penulis memberi 
wacana baru tentang strategi pendidikan Islam dalam menghadapi kemajuan Iptel di dalam era globalisasi.

\section{Pengertian Ilmu Pengetahuan dan Tekhnologi (IPTEK)}

Istilah ilmu (science) merupakan suatu perkataan yang bermakna ganda (Liang Gie 1997, 35), yaitu mengandung lebih dari satu arti. Oleh karena itu, di dalam pemakaian kata ilmu seseorang seharusnya menjelaskan makna yang dimaksud. Secara etimologi, istilah "ilmu" adalah sebagai arti dari kata "science" (bahasa Inggris), yang berarti pengetahuan. Kata ini berasal dari bahasa latin, "scientia" yang diturunkan dari kata "scire" yang berarti mengetahui (to know) dan belajar (to learn) (Liang Gie 1997, 87). Secara terminologi, pengertian ilmu sekurang-kurangnya mencakup tiga hal, yaitu pengetahuan, aktivitas, dan metode untuk mendapatkan pemahaman terhadap pengertian ilmu (Rahardjo 1996, 572).

Sementara itu, pengetahuan, menurut Jujun Surya Sumantri digolongkan menjadi tiga macam, yaitu etika (pengetahuan tentang baik dan buruk), estetika (pengetahuan tentang indah dan jelek), dan logika (pengetahuan tentang benar dan salah) (Rahardjo 1996, 24). Ilmu dan pengetahuan merupakan dua istilah yang tidak dapat dipisahkan, namun tidak selamanya bahwa pengetahuan itu sebagai ilmu, melainkan pengetahuan yang diperoleh dengan cara-cara tertentu berdasarkan kesepakatan para ilmuwan (Thoyibi 1994, 2). Ilmu sebagai pengetahuan (knowledge) adalah pengertian ilmu pada umumnya. Ilmu dikatakan sebagai aktivitas (activity) adalah serangkaian aktivitas atau kegiatan yang dilaksanakan manusia sebagaimana dikatakan oleh Charles Singer, ilmu adalah proses yang membuat pengetahuan. Istilah ilmu juga merupakan suatu metode untuk memperoleh pengetahuan yang objektif dan dapat diperiksa kebenarannya (Liang Gie 1997, 56-58).

Tiga aspek (etika, estetika, dan logika) tersebut merupakan satu kesatuan yang menunjukkan satu pemahaman bahwa ilmu terbentuk oleh aktivitas (activity) manusia yang dilakukan dengan cara atau metode tertentu sehingga pada akhirnya menghasilkan suatu pengetahuan yang sistematis. Untuk mendapatkan 
pengetahuan yang sistematis, maka harus dilakukan oleh manusia yang mempunyai kemampuan rasional, melakukan aktivitas kognitif (berkaitan dengan pengetahuan) dan mempunyai tujuan keilmuan. Ilmu adalah serangkaian aktivitas manusia yang rasional dan kognitif, dilakukan dengan beberapa metode berupa prosedur sehingga menghasilkan pengetahuan yang sistematis mengenai gejala-gejala alam, masyarakat, atau manusia dengan tujuan untuk mendapatkan kebenaran, pemahaman, memberikan penjelasan atau melakukan penerapan (Liang Gie 1997, 90-93). Singkatnya, ilmu merupakan rangkaian aktivitas berpikir yang bersifat sistematis, objektif, bermetode agar menghasilkan pengetahuan yang objektif pula.

Sementara kata tekhologi secara etimologis, berasal dari kata "techne" dan "logos". Techne berarti serangkaian prinsip atau metode rasional yang berkaitan dengan pembuatan suatu objek atau kecakapan tertentu, sedangkan logos mengacu kepada kata "logi" yang mengacu kepada makna tata piker (Tim Penyusun Fakultas Filsafat UGM 1997, 95). Secara terminologi, teknologi mempunyai arti kemampuan manusia (masyarakat) untuk memanfaatkan kekuatan-kekuatan alam guna kepentingan hidupnya. Dalam memanfaatkan kekuatan alam tersebut dilakukan dengan menciptakan alat-alat (Supriyadi 1997, 122). Dari definisi di atas, dapat disimpulkan bahwa teknologi merupakan aplikasi dari kreativitas manusia berkaitan dengan alat dan bahan, serta diwujudkan dalam bentuk materi yang digunakan untuk membantu tercapainya kebutuhan manusia.

\section{Paradoks Era Globalisasi}

Akbar S. Ahmed menggambarkan arus globalisasi yaitu "by globalization we principally refer to the rapid developments in communications technology, transport, and information which bring the remotest part of the world within easy reach" (Ahmed dan Donnan 1994, 1). Dalam konteks pendapat Ahmed di atas, globalisasi merupakan era lompatan perkembangan dalam teknologi komunikasi, transportasi dan informasi. Umat Islam 
perlu mengenali ciri-ciri tersebut dengan baik. Apabila sudah mengenali hal tersebut, maka umat Islam dapat bermain dan bersaing dalam kecenderungan kemajuan global tersebut. Hal ini dikemukakan juga oleh Alvin Toffler bahwa perubahan umat manusia dalam gelombang peradaban dapat menganalisis empat sistem yang saling berkaitan yakni, techno-sphere, info-sphere, socio-sphere, dan psycho-sphere (Toffler 1981, 325). Semua sistem tersebut akan membentuk, mempengaruhi dan menentukan dinamika masyarakat manusia. Atas kenyataan ini, dunia sekarang seringkali diidentifikasi dengan dunia sains dan teknologi. Umat manusia yang memiliki sains dan teknologi akan menguasai dunia. Jika umat Islam butuh memainkan peranannya di dunia global, maka umat Islam harus menguasai sains dan teknologi (Toffler 1981, 154). Hal ini berkaitan dengan prinsip penguasaan ilmu dalam ajaran Islam. Kegiatan ini dapat dimulai dari sikap positif terhadap kemajuan-kemajuan revolusioner dalam berbagai bidang sebagai watak era globalisasi.

Umat manusia dimanapun berada seringkali asyik dengan dunianya sendiri, hampir melupakan dunia orang lain. Padahal, banyak terjadi perubahan-perubahan besar dalam suatu sistem di luar dunianya. Pengaruh dari dunia luar sebenarnya begitu nyata. Indra Djati Sidi menuturkan bahwa dalam bidang budaya tampak adanya suatu gelombang besar berupa munculnya ide budaya global yang melanda seluruh pelosok dunia dengan kemajuan teknologi komunikasi, sehingga pengenalan budaya merupakan sesuatu yang tidak dapat dielakkan (Sidi, 2001: 14). Tentu saja, kemajuan era global selain menjadi tantangan tersendiri bagi pendidikan Islam, juga memberikan suatu peluang. Tantangannya, tidak sedikit akibat negatif yang ditimbulkan oleh kemajuan globalisasi. Akan tetapi, di sisi lain ada akibat positif dan menjadi peluang bagi umat Islam melalui pengembangan sistem pendidikan Islam yang memiliki nilai-nilai kebenaran universal. Sebab, kebutuhan umat Islam terhadap sains dan teknologi dalam rangka menjalankan tugas dan pekerjaan agar lebih mudah adalah pasti. 
Untuk membaca tantangan globalisasi bagi pendidikan Islam yaitu meneliti karakteristik globalisasi itu sendiri. Hal ini merupakan kenyataan yang kuat dapat mempengaruhi pola pemikiran dan sikap manusia. Saluran-saluran yang menjadi jalan masuknya pengaruh sudah banyak seperti: struktur sosial umat manusia, mekanisme pemerintahan, media massa, pendidikan, pemikiran, dan film. Saluran-saluran ini menjadi tantangan bagi pendidikan Islam.

Alat transportasi kian lama semakin canggih. Tingkat kecepatan maupun sistem kerja mesin semakin berinovasi. Hal ini menunjukkan relevansi dengan tingkat kebutuhan manusia yang butuh cepat dalam hitungan waktu. Semua dipenuhi melalui revolusi alat transportasi. Revolusi bidang transportasi, batasbatas negara menjadi mudah dilewati dengan aman dan nyaman. Keadaan bumi tempat manusia berpijak terasa makin kecil dan semakin sempit. Menurut para ahli geografi dan geologi, sebenarnya ukuran besarnya bumi tidak berubah (Salim, 1999: 56). Akan tetapi bumi terasa semakin kecil dirasakan oleh manusia karena teknologi transportasi berkembang dengan semakin canggih. Manusia dapat melakukan bepergian jarak jauh dengan waktu yang relatif sangat singkat.

Dalam pendidikan Islam, alat transportasi yang canggih semacam itu amat diperlukan, baik berkenaan dengan efektivitas perjalanan dakwah Islam maupun transportasi bisnis berbasis manajemen islami yang mendorong implementasi ajaran Islam dalam kehidupan sehari-hari. Para praktisi pendidikan Islam akan semakin mudah melakukan tugas-tugas pendidikan dan pengajaran hingga ke berbagai pelosok bahkan belahan dunia.

Adanya transportasi pesawat terbang di dunia muslim perlu dikembangkan secara terus menerus. Lembaga-lembaga pendidikan Islam perlu mengembangkan keahlian dalam bidang transportasi. Tokoh Indonesia seperti BJ. Habibie perlu diikuti oleh para generasi muslim sehingga terjadi regenerasi dalam bidang teknologi yang mampu memproduksi pesawat terbang. Hal ini keperluannya jelas bagi ummat Islam. Dalam era yang super sibuk, 
dimana waktu adalah kesempatan berharga yang tidak berulang, jangkauan perjalanan sudah tidak mungkin lagi dengan kecepatan kendaraan darat dan laut, melainkan jalur udara. Kemacetan yang menjadi hambatan disiplin waktu dapat dihilangkan. Dengan penguasaan bidang transportasi darat, laut dan udara maka segala kebutuhan umat Islam dapat dipenuhi secara efektif dan efisien.

Informasi berjalan sangat cepat dan luas. Hal ini terjadi pada berbagai informasi yaitu informasi positif dan informasi negatif. Walaupun menurut Sahirul Alim, bidang teknologi informatika sangat penting dan luas pengaruhnya dalam era globalisasi dewasa ini (Toffler 1981, 58). Perlu dicermati bahwa arus informasi yang mengalir dengan cepat tidak semuanya positif. Oleh sebab itu, umat Islam perlu kaya dengan informasi. Dengan itu juga, ummat Islam perlu menguasai medan-medan yang akan dilalui informasi. Umat Islam agar mampu hidup bersaing secara mantap di masa depan memang perlu cukup informasi sebagai alat untuk mengambil keputusan. Keputusan yang tidak didasarkan pada informasi yang tepat maka akan melahirkan keputusan yang keliru. Dalam hal ini benar-benar umat Islam perlu memahami perubahan sistem kehidupan akibat pengaruh informasi tersebut.

Fuad Amsyari menyatakan bahwa ada beberapa kecenderungan era global yaitu globalisasi ekonomi, perkembangan konsep swastanisasi negara, berkembangnya konsep sosialisme pasar bebas, menyempitnya nasionalisme, majunya kegiatan seni, meningkatnya peran wanita, berkembangnya dunia biologi dan suburnya spiritualisme (Amsyari 1993, 16). Tentu saja, kecenderungan tersebut, bukan hanya akibat globalisisasi tetapi wujud dinamika kebutuhan manusia itu sendiri. Hal ini yang menjadi terbuka lebar pintu negara-negara dunia untuk menerima informasi dari segala penjuru dunia.

Tantang era informasi juga dikemukakan oleh Ziauddin Sardar yang menyatakan bahwa tantangan dunia Islam abad 21 yaitu era informasi (Sardar 1989, 13). Perkembangan teknologi komputer telah menimbulkan kekuatan yang memungkinkan diperolehnya informasi hanya dengan sentuhan sebuah tombol. Teknologi 
komputer tak terelakkan lagi akan memberi bentuk baru masa depan umat manusia, mengharuskan mendefinisikan kegiatan kerja dan waktu, redefinisi pemikiran dan ilmu pengetahuan. Sebagian pemikiran memandang sejarah umat Islam pada era globalisasi yaitu sejarah dampak Barat terhadap masyarakat Islam. Menurut Fazlur Rahman, Islam dipandang sebagai suatu masa yang semi mati menerima pukulan yang destruktif pengaruh yang formatif dari Barat (Rahman 1987, 311).

Pendapat Fazlur Rahman jika dicermati lebih lanjut bahwa dampak setiap kasus adalah bersifat politis dan militer dan kaum muslim selalu dikalahkan baik secara langsung ataupun tidak langsung. Hal ini diikuti dengan bentuk-bentuk benturan keagamaan dan intelektual melalui berbagai saluran, yang beraneka ragam baik dalam tingkat kelangsungan maupun intensitasnya. Perlu disadari bahwa serangan politik suatu bangsa banyak mempengaruhi saluran informasi yang diterima. Oleh sebab itu, pengolahan informasi menjadi alat keputusan umat Islam perlu dikembangkan lebih luas pada berbagai dimensi aktivitas umat Islam termasuk bidang pendidikan Islam.

Perkembangan dan kemajuan Iptek telah mulai bermunculan, yang pada prinsipnya berkekuatan melemahkan daya mental spiritual. Permasalahan baru yang tampaknya harus segera dipecahkan oleh pendidikan Islam pada khususnya adalah dehumanisasi pendidikan dan netralisasi nilai-nilai agama. Terjadinya benturan antara nilai-nilai sekuler dengan absolutisme dari Tuhan. Akibat rentannya pola pikir manusia teknologis yang bersifat pragmatis-relativistis menuntut pendidikan Islam harus membuktikan kemampuannya dalam mengendalikan dan menangkal dampak negatif dari Iptek terhadap nilai-nilai etika keagamaan Islam serta nilai-nilai moral dalam kehidupan individual dan sosial (Hasbullah 1996, 16-18).

Perubahan dan perkembangan Iptek dengan beragam kemajuan yang dibawanya bersifat fasilitatif terhadap kehidupan manusia karena Iptek akan membawa dampak positif dan negatif (Anwar 2000, 12). Apabila kita bisa memanfaatkan teknologi 
dengan sebaik-baiknya, maka kita tidak akan terbawa arus dan hanyut ke dalam perkembangan Iptek. Namun, apabila kita tidak dapat memanfaatkan kecanggihan Iptek, maka kita akan terjerumus ke dalam dampak yang negatif. Sebab Iptek sebagai ideology baru yang membawa semangat globalitas. Globalisai Iptek masuk dalam relung-relung kehidupan umat manusia sekarang ini.

\section{Partisipasi Pendidikan Islam dalam Era Global}

Ada empat hal yang harus dilihat dalam gerak pendidikan, yaitu pertumbuhan (growth), perubahan (change), pembaharuan (development), dan keberlanjutan (sustainability) (Fadjar 2005, 267). Keempat hal ini merupakan iklim pendidikan. Pertumbuhan pendidikan Islam sudah nyata baik di Indonesia maupun di mancanegara. Khusus di Indonesia, pendidikan Islam sudah mengalami banyak perubahan dari bentuk kelompok pengajian, pesantren, madrasah hingga sekolah Islam. Oleh para pemikir pendidikan Islam, dilakukan pembaharuan-pembaharuan kurikulum, sehingga saat ini di era globalisasi pendidikan Islam tetap berlanjut. Dengan demikian, empat hal disyaratkan dalam gerak pendidikan sudah terpenuhi dalam pendidikan Islam.

Hanya saja, untuk konteks budaya global, pendidikan Islam perlu menyiapkan sumber daya manusia untuk mengisi kemajuan-kemajuan dalam berbagai bidang termasuk bidang transportasi, informasi dan komunikasi. Dalam hal ini perlu pendidikan Islam yang bermutu. Sebab, untuk menghasilkan sumber daya manusia yang bermutu diperlukan lembaga pendidikan Islam yang bermutu pula. Menurut Azyumardi Azra bahwa dalam rangka perwujudan fungsi idealnya peningkatan kualitas sumber daya manusia, sistem pendidikan Islam harus senantiasa berorientasi kepada menjawab kebutuhan dan tantangan yang muncul dalam masyarakat sebagai konsekuensi logis dari perubahan (Azra 1999, 57).

Dalam konteks global, pendidikan Islam memiliki kedudukan yang penting untuk menyiapkan sumber daya manusia yang bermutu. Karena, kompleksitas tantangan dapat mengoncangkan 
nilai-nilai keagamaan. Oleh karena itu, lembaga yang paling kompeten menyiapkan sumber daya manusia berbasis keagamaan adalah lembaga pendidikan Islam. Filosofi demikian, lembaga pendidikan Islam dapat menghasilkan sumber daya manusia yang menguasi kemajuan di bidang Iptek, sekaligus memperkokoh keimanan dan ketaqwaan, sehingga tampil moralitas yang tinggi. Peran strategis pendidikan Islam juga disinyalir oleh Abuddin Nata, bahwa dalam pendidikan Islam tidak hanya mementingkan intelektual, tetapi juga ketahanan mental spiritual yang dapat melahirkan kemampuan beradaptasi dan survive di tengah kehidupan global (Nata 2003, 171).

Dalam hal ini, pendidikan Islam harus merubah tantangan menjadi peluang, dan mengisi peluang tersebut secara produktif. Secara umum para pemikir pendidikan Islam tidak membedakan antara melanjutkan program yang ada dengan perubahan program. Melanjutkan program yang artinya program sudah ada kemudian dilanjutkan sehingga terus menerus dilaksanakan dengan baik. Sedangkan perubahan program adalah merubah program yang tidak relevan kemudian diganti dengan program yang relevan baik internal maupun eksternal.

Pendidikan dihadapkan dengan dua atau lebih alternatif tindakan dan memerlukan selektivitas untuk memilih yang lebih baik diantara alternatif tersebut. Jika suatu alternatif baru, lebih respek untuk kelangsungan program pendidikan, maka dengan sendirinya menjadi pilihan individu atau lembaga pendidikan. Namun, teori pilihan dalam memilih saja tidak cukup, karena masih perlu pencarian yang baru. Pilihan mengambil salah satu bentuk dari sejumlah alternatif. Oleh karena itu proses pengaruh beroperasi dengan membuat satu alternatif yang lebih menarik daripada yang lainnya. Pendidikan Islam harus memilih salah satu dan diperlukan inisiasi. Inisiasi khususnya dalam mendorong alternatif tindakan yang sama sekali tidak ada sebelumnya, yakni untuk memecahkan suatu masalah yang tidak ada solusi lain, atau untuk meningkatkan program sehingga dapat diterima secara memuaskan bagi customers pendidikan Islam. 
Kebanyakan riset difokuskan pada situasi memilih yang ada. Hasilnya mungkin secara subtantif tidak relevan dengan kebutuhan customers pendidikan Islam. Pekerjaan seperti ini hanya memilih-milih saja alternatif yang ada. Padahal yang diperlukan dalam pengembangan mutu pendidikan adalah pencarian rumusan baru dalam menjawab perubahan kondisi dinamis masyarakat global. Oleh karena itu yang perlu mendapat perhatian bagi pendidikan Islam yaitu melakukan inisiasi. Tidak semua perubahan dapat disebut sebagai proses inisiasi. Inisiasi di sini adalah perubahan yang memerlukan pemikiran dan evaluasi program capaian baru yang sebelumnya tidak bisa diperkenalkan oleh suatu aplikasi sederhana. Untuk memahami apakah sistem pendidikan Islam berubah karena adanya inisiasi atau bukan, dapat dilihat dalam batasan kompleksitas strategi dan pengaturan yang diikat oleh bentuk capaian program. Jika tergambarkan bagian-bagian sistem pendidikan seperti program baru dan mekanisme pengaturannya yang baru, maka kita dapat menyebut perubahan tersebut dengan perubahan inisiasi program baru.

Selanjutnya, pendidikan Islam juga perlu melakukan inovasi. Proses inovasi adalah hal penting dalam lembaga pendidikan Islam yang berhubungan erat dengan pemikiran produktif dan pemikiran kreatif. Sebagai titik awal kita perlu mengetahui masalah proses pemecahan masalah di level individu, dan kemudian mempertimbangkan pada level institusi pendidikan Islam. Kenyataannya semua manusia secara individu dapat memecahkan masalah, dan akal memainkan peran penting di dalamnya. Tipe pemecahan masalah berguna sebagai unsur produktivitas yang ada, bergantung pada karakteristik masalah dan pengalaman di masa lalu dari seorang pimpinan lembaga pendidikan Islam.

Dalam era globalisasi, inovasi dapat dilakukan sebagai akibat dari tantangan yang kemudian diperhitungkan sebagai peluang. Selanjutnya, perlu mencernati peluang inovasi dan waktu inovasi. Kedua-duanya berkaitan dengan proses perubahan pendidikan Islam secara inovatif. Peluang inovasi terkait dengan keadaan 
lingkungan yang selalu berubah yang mendorong pendidikan Islam untuk merubah program. Sedangkan waktu inovasi terkait dengan tahapan langkah yang harus diikuti sesuai aspirasi yang terjadi. Dalam organisasi pendidikan, perlu membuat unit perencanaan. Umumnya, hal ini terkait pula dengan istilah deadline, sehingga perlu menentukan skala prioritas secara hirarkis.

\section{Pendidikan Islam Berwawasan Etos Kerja dan IPTEK}

Pada hakikatnya, ilmu pengetahuan dan teknologi merupakan hasil karya dari potensi akal manusia. Perkembangan Ilmu pengetahuan dan teknologi saat ini berlangsung sangat cepat dan mencakup semua sektor kehidupan manusia. Sejalan dengan pesatnya perkembangan ilmu pengetahuan dan teknologi, pendidikan sebagai bagian dalam kebudayaan manusia tidak akan lepas dari berbagai tantangan. Adapun yang menjadi titik sentral problem adalah standar kehidupan yang berpijak pada materialisme dan sekularisme (Gauhar 1982, 340). Hal ini mendorong manusia untuk memusatkan diri pada perkembangan ilmu pengetahuan dan informasinya sebagai sumber strategis dalam pembaharuan.

Oleh karenanya tidak terpenuhinya kebutuhan ini akan menyebabkan depersonalisasi dan keterasingan oleh dunia modern (Bell 1976, 12). Untuk menghadapi berbagai tantangan dan dampak di atas, maka pendidikan Islam harus mampu untuk meminimalisir dampak negatif dari kemajuan Iptek, di antaranya dengan cara perbaikan kembali konsep dan sistem pendidikan yang ada. Konsep tersebut perlu disesuaikan dengan kehidupan modern; merumuskan kembali konsep sosial dan Ilmu Pengetahuan Alam (IPA); menyusun kembali kurikulum; dan para pendidik perlu dilatih kembali sehingga mereka mampu menanamkan nilai-nilai serta mengembangkan kemampuan intelektual dengan metode pengajaran yang efektif. Dengan demikian, pendidikan Islam akan menjadi pendidikan yang sejati.

John Naisbitt dan Patricia Aburdene sebagaimana dikutip A. Malik Fadjar, pernah mengatakan bahwa terobosan paling 
menggairahkan dari abad XXI yaitu, konsep yang luas tentang apa artinya manusia itu. Pengembangan kualitas SDM bukan persoalan yang gampang dan sederhana, karena membutuhkan pemahaman yang mendalam dan luas pada tingkat pembentukan konsep dasar tentang manusia serta perhitungan yang matang dalam penyiapan institusi dan pembiayaan (Fadjar 2005, 267). Paradigma pembangunan yang berorientasi pada keunggulan komparatif dengan lebih mengandalkan sumber daya alam dan tenaga kerja yang murah, saat ini mulai mengalami pergeseran menuju pembangunan yang lebih menekankan keunggulan kompetitif. Dalam paradigma baru ini, kualitas SDM, penguasaan teknologi tinggi dan peningkatan peran masyarakat memperoleh perhatian (Fadjar 2005, 157).

Keberhasilan pembangunan terutama ditentukan oleh kualitas manusianya, bukan oleh melimpah-ruahnya kekayaan alam (Sardar 1989, 20). Dalam pembangunan, manusia adalah perencana, pelaku, pengendali serta tujuan dari pembangunan itu sendiri. Oleh karena itu pengembangan kualitas sumber daya manusia merupakan prioritas utama yang harus ditingkatkan, sehingga dengan demikian ia dapat memiliki segala kemampuan yang dibutuhkan dalam pembangunan di segala bidang.

Upaya pengembangan dan peningkatan kualitas sumber daya manusia dapat dilakukan melalui berbagai jalur, diantaranya melalui pendidikan. Pendidikan ini merupakan jalur peningkatan kualitas sumber daya manusia yang lebih menekankan pada pembentukan kualitas dasar, misalnya keimanan dan ketakwaan, kepribadian, kecerdasan, kedisiplinan, kreativitas dan sebagainya (Sidi 2001, 11).

Dalam hal pengembangan SDM, pendidikan memiliki nilai strategis dan mempunyai peran penting sebagai suatu investasi di masa depan. Karena secara teoretis, pendidikan adalah dasar dari pertumbuhan ekonomi, dasar dari perkembangan sains dan teknologi, mengurangi kemiskinan dan ketimpangan dalam pendapatan, dan peningkatan kualitas peradaban manusia pada umumnya (Rakhmat 1997, 71). Nilai strategis pendidikan yang 
makro ini, menyimpulkan bahwa pendidikan menyimpan kekuatan luar biasa untuk menciptakan keseluruhan aspek lingkungan hidup dan dapat memberikan informasi paling berharga mengenai pegangan hidup di masa depan serta membantu anak didik mempersiapkan kebutuhan hidup yang esensial untuk menghadapi perubahan.

Untuk menjawab tuntutan dan tantangan global, keunggulan-keunggulan mutlak yang harus dimiliki umat Islam Indonesia adalah penguasaan atas sains teknologi dan keunggulan kualitas sumber daya manusia yang mumpuni. Kemajuan dan penguasaan atas sains teknologi akan mendorong terjadinya percepatan transformasi masyarakat dalam berbagai bidang kehidupan, yang di Indonesia lebih dikenal dengan istilah pembangunan (Azra 1999, 46).

Merasuknya globalisasi, berkembangnya profesionalisasi dan semakin menajamnya kompetisi antar negara, menuntut adanya pelurusan orientasi pembangunan pada peningkatan kualitas manusia. Di negara-negara maju, SDM menjadi prioritas utama dalam pembangunan pendidikan, SDM dipandang sebagai pilar utama infrastruktur yang mapan di bidang pendidikan. Kondisi ini berbeda dengan pendidikan di Indonesia yang dihadapkan pada persoalan penyediaan SDM. Adanya ketidakcocokan dan ketidaksepadanan antara output di semua jenjang pendidikan dengan tuntutan masyarakat (social demands) dalam dunia kerja adalah satu contoh pekerjaan rumah bagi dunia pendidikan di Indonesia yang harus segera dibenahi. Pendidikan masih lebih memperlihatkan sebagai suatu beban dibanding sebagai suatu kekuatan dalam pembangunan. Dipandang dari perspektif human capital theory, pendidikan Islam dihadapkan pada persoalan underinvestment in human capital, yaitu kurang dikembangkannya seluruh potensi SDM yang sangat dibutuhkan bagi pembangunan. Akibatnya, pendidikan di Indonesia masih belum menunjukkan tingkat balik (rate of return) yang dapat diukur dari besarnya jumlah lulusan pendidikan yang terserap ke dalam dunia kerja (Gibb 1978, 15). Dahulu, 
pendidikan lebih merupakan model untuk pembentukan maupun pewarisan nilai-nilai keagamaan dan tradisi masyarakat. Artinya, misi pendidikan dianggap berhasil ketika anak didik sudah mempunyai sikap positif dalam beragama dan memelihara tradisi masyarakatnya (Fadjar 2005, 9).

Kini, paradigma pendidikan seperti itu harus direkonstruksi agar sumber daya manusia Muslim tidak acuh terhadap persoalan yang terkait dengan kepentingan ekonomi, ketenaga-kerjaan, dan persoalan lainnya dengan tetap mempertahankan nilai-nilai etik dan moral Islam. Titik sentral yang menjadi kunci berhasil atau tidaknya suatu bangsa dalam membangun negaranya, tergantung dengan kualitas sumber daya manusianya. Penulis berpendapat, Islam, khususnya di Indonesia, bisa bangkit dengan muslim yang kuat dan berkualitas jika memiliki tiga faktor yang telah terpenuhi, yaitu iiman, ilmu, dan amal shalehî atau perbuatan produktif yang menjadi indikator tinggi rendahnya mutu sumber daya manusia. Manusia yang memiliki iman teguh, ilmu yang tinggi dan bermanfaat serta kerja yang produktif merupakan sumber daya manusia unggul yang harus diwujudkan di masa yang akan datang. Kompleksnya persoalan pendidikan di satu sisi dan tuntutan meningkatkan kualitas sumber daya manusia di sisi lain menyebabkan persoalan pendidikan tetap menarik untuk dibahas dengan harapan pembahasan ini mampu memunculkan solusi alternatif dalam mengembangkan kualitas sumber daya manusia lewat jalur pendidikan Islam.

Titik tolak yang baik bagi pembaharuan sistem pendidikan Islam dan merupakan solusi agar pendidikan Islam dapat mengikuti modernisasi serta perkembangan ilmu pengetahuan dan teknologi adalah dengan tetap berpegang teguh pada kendali normative,yaitu al-Quran dan al-Hadis. Oleh karena dalam pendidikan Islam ada dua tujuan yang harus dicapai, yaitu tujuan jangka panjang (kebahagiaan ukhrawiah) dan tujuan jangka pendek (kebahagiaan duniawiah). Pendekatan ini juga sebagai reaksi terhadap maraknya suatu pendapat yang menyatakan bahwa sekitar abad ke-13 M sampai abad ke-19 M dari segi keagamaan. Pada saat itu Islam telah 
membeku (semi mati), dalam arti tetap berada dalam bentukbentuk yang telah diciptakan oleh para ulama, qadi (hakim agama), mujtahid, dan tokoh sufi pada masa-masa pembentukannya dan seandainya ada perubahan hanya menjurus pada kemunduran bukan kepada kemajuan (Gibb 1978, 1).

Demikian gambaran singkat mengenai Pendidikan Islam dan kemajuan ilmu pengetahuan dan teknologi. Menurut penulis, semua ini terjadi karena prinsip-prinsip serta nilai-nilai yang ada dalam agama Islam itu bukan hanya berlaku untuk satu masa tertentu dan untuk satu golongan tertentu pula, tetapi berlaku untuk sepanjang jaman dan untuk semua umat manusia (rahmatan lil alamiin).

\section{Penutup}

Berdasarkan uraian di atas, dalam membuktikan partisipasi pendidikan Islam dalam konteks budaya global, strategi yang perlu ditempuh. Pertama, melaksanakan inisisai dan inovasi kelembagaan pendidikan Islam secara sistemik, total dan mendasar. Kedua, meningkatkan kualitas akademik (pengajaran, penelitian dan pengabdian). Ketiga, meningkatkan relevansi pendidikan Islam dengan kebutuhan internal dan eksternal. Keempat, meningkatkan peranan dalam percaturan internasional. Di samping itu, dalam konteks budaya global, pendidikan Islam perlu dikelola dengan melihat peluang dan kondisi riil yang harus dihadapi. Eksistensi pendidikan Islam yang berlandaskan pada teori input-output analysis perlu diganti dengan teori proses konteks analisis. Hal ini didasarkan pada dinamika manusia sebagai pelaku pendidikan Islam dalam dunia global.

Pendidikan Islam harus bersikap mengarahkan dan mengendalikan perkembangan ilmu pengetahuan dan teknologi sehingga tetap berpijak pada sumber agama Islam, yaitu al-Quran dan al-Hadis. Ada dua strategi yang ditawarkan dalam pendidikan Islam, yaitu strategi global dan strategi sektoral. Dalam strategi global, ada dua pendekatan, yakni pendekatan sistemik dan pendekatan proses. Dalam strategi sektoral ada tiga pendekatan 
penguasaan teknologi informasi dan komunikasi. Dengan strategi dan pendekatan di atas, diharapkan pendidikan Islam dapat memproduk para ilmuwan Muslim yang mampu menguasai dan menciptakan Iptek yang berpijak pada nilai-nilai islami serta berorientasi kepada kesejahteraan dunia dan akhirat.

\section{Daftar Pusaka}

Ahmad, Amrullah. 1991. Pendidikan Islam di Indonesia antara Cita dan Fakta. Yogyakarta: Tiara Wacana.

Ahmed, Akbar S. dan Hastings Donnan. 1994. Islam, Globalization and Postmodernity. London: Routledge.

Amsyari, Fuad. 1993. Masa Depan Umat Islam Indonesia. Bandung: AlBayan.

Anwar, Chairil. 2000. Islam dan Tantangan Kemanusiaan Abad XXI. Yogyakarta: Pustaka Pelajar.

Azra, Azyumardi. 1999. Pendidikan Islam, Tradisi dan Modernisasi Menuju Milenium Baru. Jakarta: Logos.

Bell, Daniel. 1976. The Coming of Post Industrial Society. Basic Book Inc: Harper Coloption.

Fadjar, Malik. 2005. Holistika Pemikiran Pendidikan. Jakarta: Rajawali Press.

Gauhar, Altaf. 1982. Tantangan Islam, terj. Anas Mahyudin. Bandung: Pustaka.

Gibb, H.A.R. 1978. Modern Trends In Islam. New York.

Gie, The Liang. 1997. Pengantar Filsafat Ilmu. Yogyakarta: Liberty.

Hasbullah. 1996. Kapita Selekta Pendidikan Islam. Jakarta: Raja Grafindo Persada.

Nata, Abuddin. 2003. Manajemen Pendidikan: Mengatasi Kelemahan Pendidikan Islam di Indonesia. Jakarta: Kencana.

RHA. Sahirul Alim. 1999. Menguak Keterpaduan Sains, Teknologi dan Islam. Yogyakarta: Titian Ilahi Press.

Rahardjo, M. Dawam. 1996. Ensiklopedi al-Quran: Tafsir Sosial Berdasarkan Konsep-konsep Kunci. Jakarta: Paramidana.

Rahman, Fazlur. 1987. Islam Modern: Tantangan Pembaharuan Islam. Yogyakarta: Salahuddin Press. 
1997. Islam, terj. Ahsin Muhammad. Bandung: Pustaka.

Rakhmat, Jalaluddin. 1997. Islam Alternatif. Bandung: Mizan.

Sardar, Ziauddin. 1989. Tantangan Dunia Islam Abad 21: Menjangkeau Informasi, terj. A.E. Priyono dan Ilyas Hasan. Bandung: Mizan.

Sidi, Indra Djati. 2001. Meniju Masyarakat Belajar. Jakarta: Paramadina.

Supriyadi, Dedi. 1997. Kreativitas, Kebudayaan, dan Perkembangan Iptek. Bandung: Alfabeta.

Thoha, Chabib. 1996. Kapita Selekta Pendidikan. Yogyakarta: Pustaka Pelajar.

Thoyibi. M. 1994. Filsafat Ilmu dan Perkembangannya. Surakarta: Muhammadiyah University Press.

Tim Penyusun Fakultas Filsafat UGM. 1997. Filsafat Ilmu sebagai Dasar Pengembangan Ilmu Pengetahuan. Yogyakarta: Intan Pariwara.

Toffler, Alvin. 1981. The Third Wave. London: Bantam Books. 